\title{
Some Aspects on the Reproductive Biology of an Endemic Catfish, Arius manillensis Valenciennes, 1840 (Siluriformes: Ariidae), of Laguna de Bay, Philippines
}

\author{
Alfonso, Noel F. ${ }^{1 *}$ and Ramos, Gliceria B. ${ }^{1 *}$ \\ ${ }^{1}$ Biology Department, College of Science, De La Salle University, Taft Avenue, Manila, Philippines \\ *Corresponding author: noel.alfonso@dlsu.edu.ph, gliceria.ramos@dlsu.edu.ph \\ Received: 24 $4^{\text {th }}$ Jan $2019 \quad$ Accepted: 10 ${ }^{\text {th }}$ Jun 2019 \\ Published: $28^{\text {th }}$ Aug 2019
}

DOI: https://doi.org/10.22452/mjs.vol38no2.1

\begin{abstract}
Arius manillensis is an endemic and economically important catfish of Laguna de Bay, Philippines. This study generated data on some aspects of its reproductive biology that are vital for the enhancement of propagation efforts for inland fisheries in the Southeast Asian region. Monthly assessments were conducted for one whole year to establish the distinct spawning season(s) through determinations of gonadosomatic index (GSI), fecundity through counting the number of two stages of follicles, and size at sexual maturity. Sex ratio was taken into account. Peaks in GSI occurred in March to April and July to August. These peaks correspond with months of peaks in fecundity. The parallel patterns of these reproductive aspects strengthen the occurrence of two distinct spawning seasons. GSI did not show significant correlation with body parameters while fecundity was significantly correlated with body weight (BW) and length (BL) and gonad weight $(\mathrm{GW})$. Size and weight of apparent sexual maturity or peak reproductive capacity is about $20 \mathrm{~cm}$ and $200 \mathrm{~g}$, respectively. Sex ratio was female-biased (2.11:1). Female dominance indicates a unique reproductive behavior of A. manilensis where males could have evolved survival mechanism(s) to elude capture during breeding seasons and evidently during spawning on the cold months.
\end{abstract}

Keywords: Arius manillensis, fecundity, gonadosomatic index, Laguna de Bay, spawning, sex ratio

\section{INTRODUCTION}

The sea catfish, Arius manillensis, commonly named "kanduli", is one of the six species of the Family Ariidae in the Philippines (Vallejo, 1985). It belongs to the Order Siluriformes (silures, catfishes) and the Family Ariidae (sea catfishes, fork-tailed catfishes). A. manillensis occurs limitedly in the waters of Laguna de Bay and is known as the native species that commands high economic value (Vallejo, 1985). Based on latest available record Fishbase.org (2014), this commercial fish has a record catch of 745 metric tons.
However, its fingerlings are not available for fish farming purposes (FAO, 1972). There had been recommendations by FAO way back in the 1970s for experimental work to be undertaken on the propagation of this native species.

Based on the survey of related literature to date, very limited studies have been reported on the biology of A. manillensis. Mane (1929) conducted preliminary study on its life history and feeding habits. Mercene (1978) conducted population survey, noting the trend and/or fluctuation of kanduli fisheries in Laguna Lake. Recent 
morphological and genetic work on the species has been done also by Santos and Quilang (2012) and Yu and Quilang (2015). Despite its considerable economic importance, no further work has been conducted specifically on its reproductive biology. Mansor et al. (2012) reported on the sex ratio, fecundity, egg diameter, and gonado-somatic index (GSI) on the estuarine catfish, Arius argyropleuron in Malaysia. Another Malaysian study, Mazlan at al. (2008) examined the basic reproduction of spotted catfish Arius maculatus. A recent paper by Ambily and Nandan (2017) showed that for Shovelnose catfish, Arius subrostratus, the spawning season, based on GSI, was from September to November. It is therefore the intent of this study to investigate this biological aspect taking into account the spawning season, size at sexual maturity, and fecundity of this native species. Knowledge of the aforementioned reproductive dynamics is essential for developing effective management measures and propagation efforts into other potential sites due to its importance in inland fishery.

\section{MATERIALS AND METHODS}

\section{Collection of fish samples}

Monthly collections of Arius manillensis samples were done for twelve months, from August 2010 to July, 2011 in Los Banos, a lakeside town on the southern shores of Laguna de Bay, Philippines with coordinates of $14.1667^{\circ} \mathrm{N}, 121.2167^{\circ} \mathrm{E}$ (Figure 1). It encompasses several barangays that are economically dependent on fish catch from the lake.

The collected fish samples (Figure 2) were immediately frozen in styropor boxes and transported to the Developmental Biology Laboratory, De La Salle University, Manila.

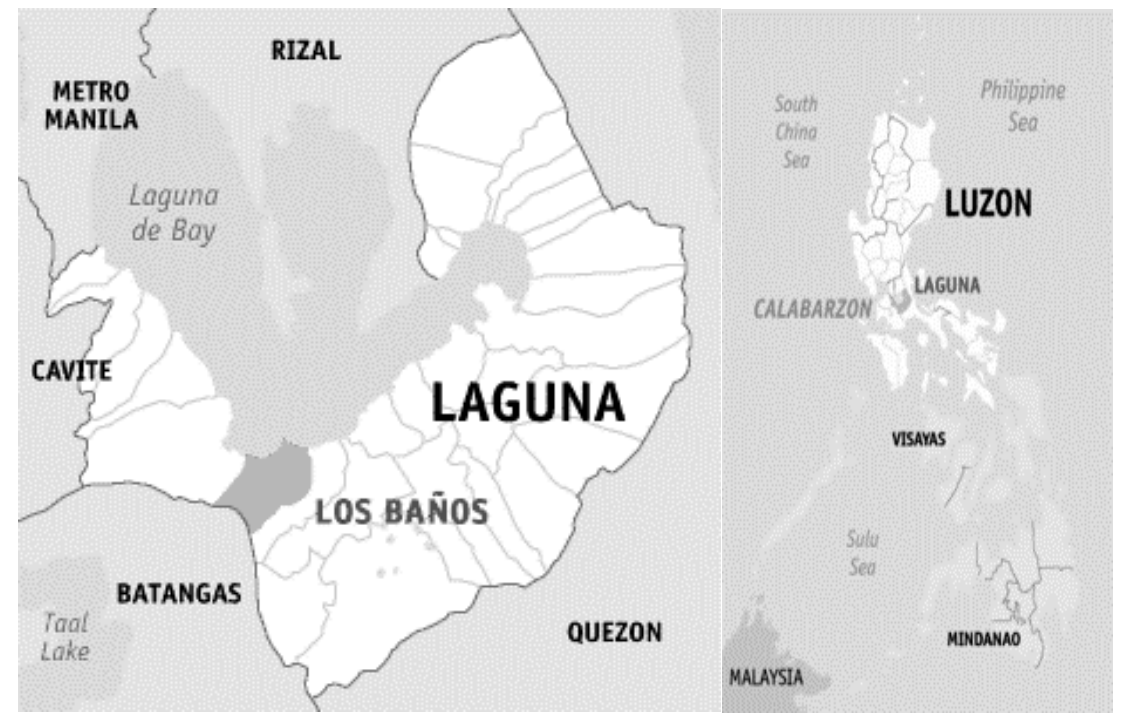

Figure 1. Map of Laguna de Bay, Philippines showing the nearby town of Los Banos,

Laguna Province. The site of collection is indicated by double-headed arrow. (Source of map: http://upload.wikimedia.org/wikipedia/commons/thumb/7/7d/Ph_locator_laguna_los_banos.pn g/250px-Ph_locator_laguna_los_banos.png;

(http://www.zamboanga.com/z/images/8/84/Laguna_philippines_map_locator.png) 


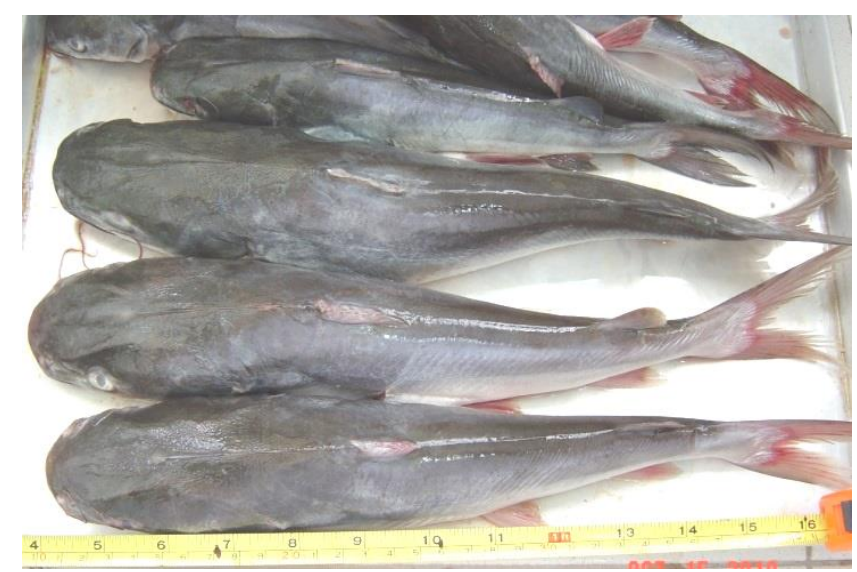

Figure 2. The freshly collected samples of A. manilensis from Laguna de Bay, Philippines (X1)

\section{Dissection of fish samples and} determination of sex ratio

The abdominal cavity of the fish was exposed and the gonads visually examined to determine the sex of the sample. Monthly variation in sex ratio was determined after counting the total number of both sexes from the monthly collected samples. A chi-square test was performed to assess whether there are significant differences in sex ratio from the expected ratio of $1: 1$.

\section{Measurements of morphometric parameters, determination of GSI as indicator of spawning season, and classification of oocytes, based on diameter measurements, for the determination of fecundity}

Standard body length (BL) from snout to tail end was measured to the nearest 0.5 centimeter $(\mathrm{cm})$ and body weight $(\mathrm{BW})$ to the nearest gram. The spawning periodicity was determined by monthly evaluation of the gonadosomatic index (GSI) of each fish sample. The gonads weights (GW) were determined on an analytical balance to the nearest 0.001 gram. GSI was calculated using the formula employed by Marcano et al. (2007), Sarkar et al. (2012), and Gupta and Banerjee (2013).
Gonadosomatic index $(G S I)=$ Gonad weight $(G W) /$ Total Body weight (BM) $X 100$

Gravid ovaries were dissected, and the follicles were counted and each follicular diameter was measured using a digital caliper to the nearest $0.1 \mathrm{~mm}$. The follicles were classified into 4 stages based on diameter: Stage 1 (Pre-vitellogenesis): 1.6-2.8 mm; Stage 2 (Endogenous-vitellogenesis): 2.9-6.5 $\mathrm{mm}$; Stage 3 (Exogenous vitellogenesis): 6.6$7.8 \mathrm{~mm}$; and Stage 4 (Ripe pre-ovulatory): $>7.8 \mathrm{~mm}$. (Adapted from de Graaf, 1994)

Determined Fecundity (DF) was calculated using the formula below, where the total counts of ovarian follicles in Class 3 and 4 were summed up.

$F=$ Total number of follicles in Classes $3 \&$ 4 from pair of ovaries.

\section{Data Analysis}

All data were tabulated on MS Excel sheets, and subjected to various statistical analyses on the VassarStats website, an online statistical facility of Vassar College, New York, USA (vassarstats.net) and MS Excel (Microsoft Office Professional Plus 
2010). Sex ratio significance was determined using Chi-square "goodness of fit test". BW, $\mathrm{BL}, \mathrm{GW}$ and GSI were plotted to compare month to month variations for male and female, respectively. ANCOVA was used to test any covariance between male and female in terms of BW and BL. Correlation analysis was conducted on BW vs BL, BW vs GSI and BL vs GSI for both male and female, respectively. Mean monthly fecundity was plotted to compare month to month variations. Correlation and multiple regression analyses were also conducted on BW vs F, BL vs F and GW vs F. Regression equations for all correlations were obtained and tested for significance.

\section{RESULTS}

\section{Sex Ratio}

There was a highly significant $(p<0.0001)$ annual (total) sex ratio of 1: 0.47 in favor of female. Males were significantly $(p<0.05)$ lower in number than females in August, November, February, and July. Males were highly significantly $(\mathrm{P}<0.01)$ lower in number than females during December and March. (Table 1). There was no significant difference from a 1:1 ratio in the months of September, October, January, April, May, and June.

Table 1. The sex ratio of $A$. manilensis within an annual period from the month of August to the month of July

\begin{tabular}{lcccccc}
\hline \multicolumn{1}{c}{ Month } & Male (n) & Female (n) & F:M & $\begin{array}{c}\text { Chi- } \\
\text { square }\end{array}$ & $\boldsymbol{P}$ & Remarks \\
\hline August & 15 & 33 & $1: 0.45$ & 6.75 & 0.0141 & S \\
\hline September & 18 & 22 & $1: 0.82$ & 0.4 & 0.639 & NS \\
\hline October & 23 & 38 & $1: 0.60$ & 3.69 & 0.0727 & NS \\
\hline November & 4 & 15 & $1: 0.27$ & 6.37 & 0.0218 & S \\
\hline December & 6 & 21 & $1: 0.29$ & 8.33 & 0.0071 & HS \\
\hline January & 10 & 22 & $1: 0.45$ & 4.5 & 0.0519 & NS \\
\hline February & 7 & 21 & $1: 0.33$ & 7.0 & 0.014 & S \\
\hline March & 9 & 28 & $1: 0.32$ & 9.76 & 0.0031 & HS \\
\hline April & 12 & 17 & $1: 0.71$ & 0.86 & 0.4543 & NS \\
\hline May & 8 & 18 & $1: 0.44$ & 3.85 & 0.0773 & NS \\
\hline June & 10 & 19 & $1: 0.53$ & 2.79 & 0.138 & NS \\
\hline July & 9 & 23 & $1: 0.39$ & 6.13 & 0.0216 & S \\
\hline $\begin{array}{l}\text { Annual (Total) } \\
\text { Monthly }\end{array}$ & $\mathbf{1 3 1}$ & $\mathbf{2 7 7}$ & $\mathbf{1 : 0 . 4 7}$ & $\mathbf{5 2 . 2 5}$ & $<.0001$ & HS \\
Average & $\mathbf{( 1 0 . 9 1 )}$ & $\mathbf{2 3 . 0 8 )}$ & & & & \\
\hline
\end{tabular}

$n=$ sample size; $F: M=$ female:male $; P=P$-value $; N S=$ not significant $(P>0.05) ; S=$ significant $(P<0.05)$; $H S=$ highly significant $(P<0.01)$

\section{GSI}

The monthly mean GSI for males was consistently low throughout the year $(0.1030 \pm 0.0789)$ while females showed peaks in July to August and bottom declines from September to February. The peaks recurred in March to April. GSI in May is comparable with that of February but with slight upswing in June (Figure 3). 


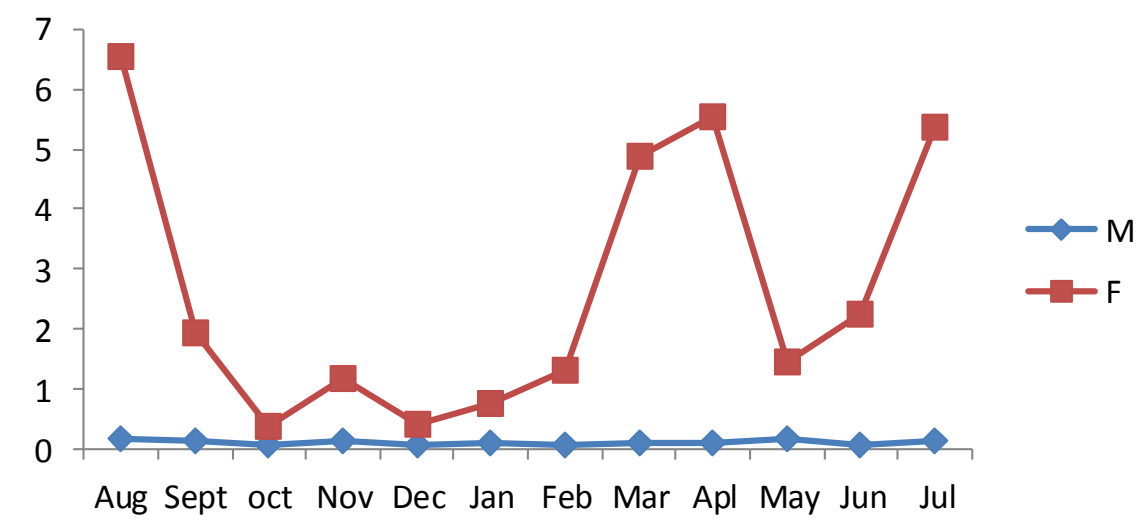

Figure 3 . The monthly mean gonadosomatic index (GSI) of $A$. manilensis recorded for a year from the month of August to the month of July

\section{Stages of follicle maturation and Fecundity}

2; Figure 4)

There were four stages of follicle maturation based on the diameter measurements (Table

Table 2. Numbers (monthly \%) of the stages* of follicle maturation of A. manilensis with the

\begin{tabular}{cccccc}
\hline Month & $\begin{array}{c}\text { Stage 1 } \\
(\mathbf{1 . 6 - 2 . 8})\end{array}$ & $\begin{array}{c}\text { Stage 2 } \\
(\mathbf{2 . 9 - 6 . 5 )}\end{array}$ & $\begin{array}{c}\text { Stage 3 } \\
(\mathbf{6 . 6 - 7 . 8})\end{array}$ & $\begin{array}{c}\text { Stage 4 } \\
(>\mathbf{7 . 9})\end{array}$ & Total \\
\hline Aug & $314(61.1 \%)$ & $57(11.1 \%)$ & $43(8.4 \%)$ & $100(19.6 \%)$ & $514(100 \%)$ \\
\hline Sep & $10(12.2 \%)$ & $0(0 \%)$ & $0(0 \%)$ & $72(87.8 \%)$ & $82(100 \%)$ \\
\hline Oct & $26(19.4 \%)$ & $84(62.7 \%)$ & $0(0 \%)$ & $24(17.9 \%)$ & $134(100 \%)$ \\
\hline Nov & $18(8.5 \%)$ & $105(49.5 \%)$ & $28(13.2 \%)$ & $61(28.8 \%)$ & $212(100 \%)$ \\
\hline Dec & $110(35.2 \%)$ & $94(30.1 \%)$ & $47(15.1 \%)$ & $61(19.6 \%)$ & $312(100 \%)$ \\
\hline Jan & $247(56.4 \%)$ & $91(20.8 \%)$ & $58(13.2 \%)$ & $42(9.6 \%)$ & $438(100 \%)$ \\
\hline Feb & $177(42.3 \%)$ & $148(35.3 \%)$ & $57(13.6 \%)$ & $37(8.8 \%)$ & $419(100 \%)$ \\
\hline Mar & $1325(69.4 \%)$ & $257(13.4 \%)$ & $158(8.3 \%)$ & $170(8.9 \%)$ & $1910(100 \%)$ \\
\hline Apr & $1024(60.8 \%)$ & $427(25.3 \%)$ & $5(0.3 \%)$ & $229(13.6 \%)$ & $1685(100 \%)$ \\
\hline May & $226(52.4 \%)$ & $116(26.9 \%)$ & $35(8.1 \%)$ & $54(12.6 \%)$ & $431(100 \%)$ \\
\hline Jun & $172(36.7 \%)$ & $151(32.3 \%)$ & $22(4.7 \%)$ & $123(26.3 \%)$ & $468(100 \%)$ \\
\hline Jul & $254(39.2 \%)$ & $137(21.2 \%)$ & $61(9.4 \%)$ & $195(30.1 \%)$ & $647(100 \%)$ \\
\hline
\end{tabular}

corresponding range of diameter measurements $(\mathrm{mm})$ of each stage.

*Stage 1: Pre-vitellogenesis; Stage 2: Endogenous-vitellogenesis; Stage 3: Exogenous vitellogenesis; and Stage 4: Ripe pre-ovulatory. (Adapted from de Graaf, 1994) 


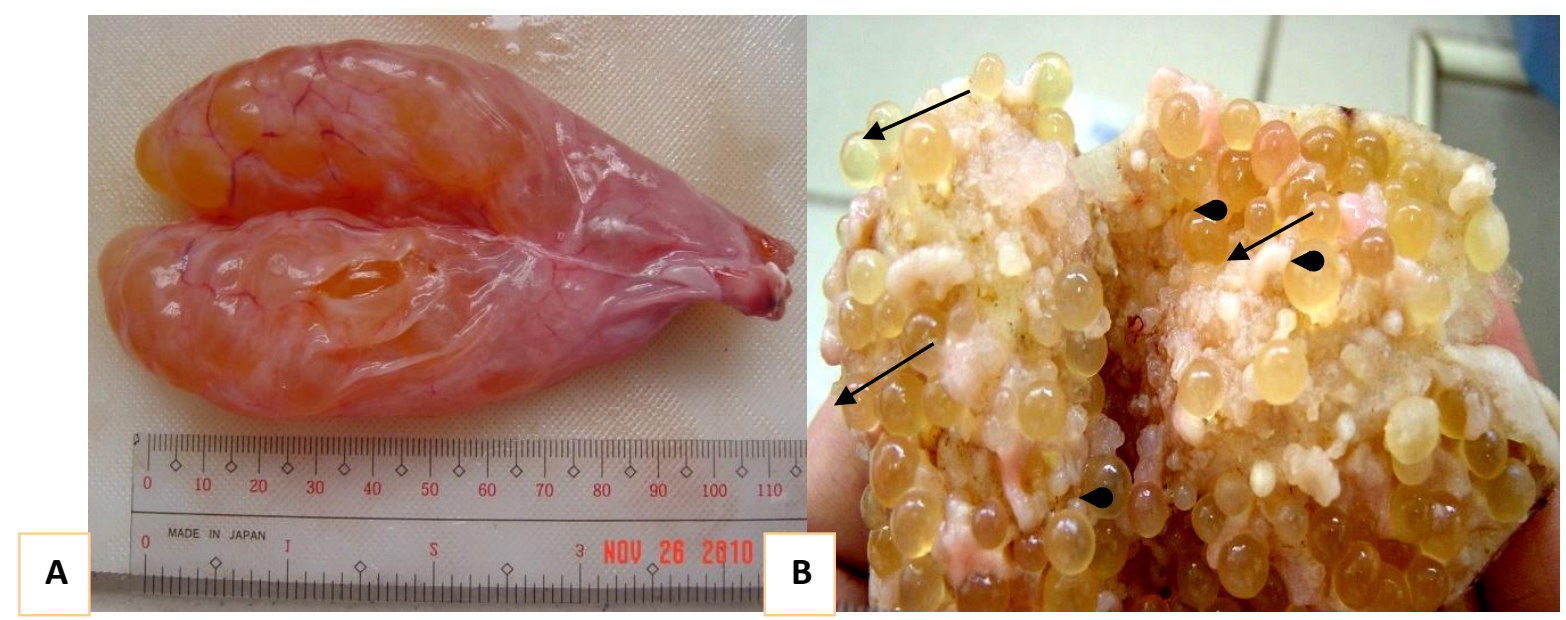

Figure 4. The maturity stages of $A$. manilensis oocytes classified into stages 1 to 4 based on diameter measurements. (A) A gravid and intact ovary (B) Bunch of oocytes showing various stages of eggs, with stage 3 oocytes indicated by black teardrops and stage 4 oocytes indicated by black arrows.

A total of 7252 follicles were measured. The monthly distribution revealed that the Stage 4 ripe preovulatory eggs $(>7.8$ $\mathrm{mm})$ were most predominant in September $(87.8 \%)$ and least in February and March (8.8\% and $8.9 \%$, respectively). The Stage 3 exogenous vitellogenesis eggs $(6.6-7.8 \mathrm{~mm})$ constituted $13-15 \%$ of the follicles in November, December, January and February. None of these Stage 3 and 4 follicles were observed in September and October. Stage 2 endogenous vitellogenesis eggs (2.9-6.5 mm) were highest in October $(62.7 \%)$ and
November (49.5\%) and absent in September. Small Stage 1 pre-vitellogenesis eggs (1.6$2.8 \mathrm{~mm}$ ) were highest in March (69.4\%), August (61.1\%) and April (60.8\%). These eggs were lowest in November $(8.5 \%)$.

Fecundity was high in August but tapered off in September onwards to February. Highest peaks were recorded in March and April, dipped down in May but with upswing in June comparable with that of August (Figure 5).

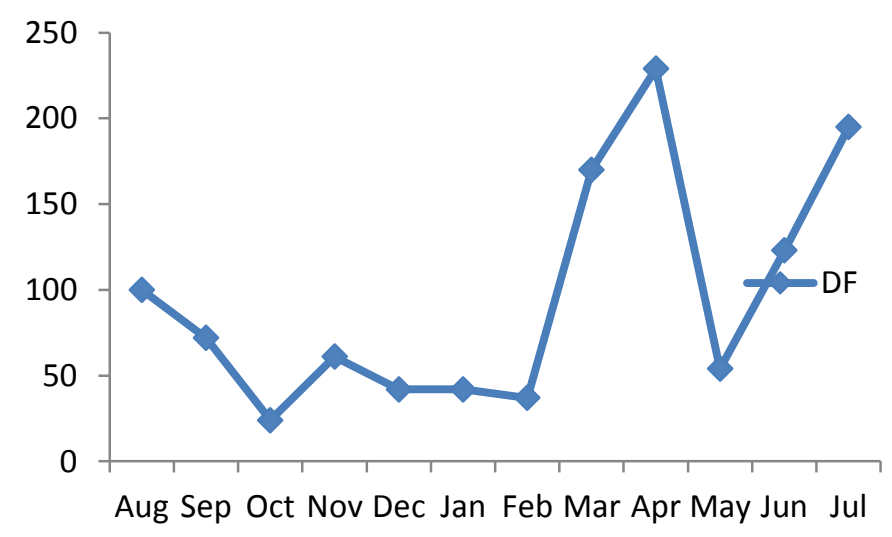

Figure 5. The monthly mean determined fecundity (DF) of A. manilensis recorded for a year from the month of August to the month of July 
Correlation analyses of GSI vs body weight $(B W)$ and body length (BL) and Fecundity vs $B W$ and $B L$

Female GSI was found not significantly $\left(P=0.28 ; r^{2}=0.004\right)$ correlated with $\mathrm{BW}$ and likewise weakly correlated negatively with $\mathrm{BL}\left(\mathrm{r}^{2}=0.03\right)$ (Figure 6 )
Male GSI was not significantly correlated $\left(\mathrm{P}=0.7 ; \mathrm{r}^{2}=0.001\right)$ with $\mathrm{BW}$ nor with $\mathrm{BL}, \quad\left(\mathrm{P}=0.4 ; \mathrm{r}^{2}=0.004\right)$ as shown in Figure 7.

It was noted, however that female GSI was clustered around 20 to $40 \mathrm{~cm} \mathrm{BL}$ and this was statistically significant. A similar clustering of male GSI was observed at 20 to $40 \mathrm{~cm} \mathrm{BL}$.

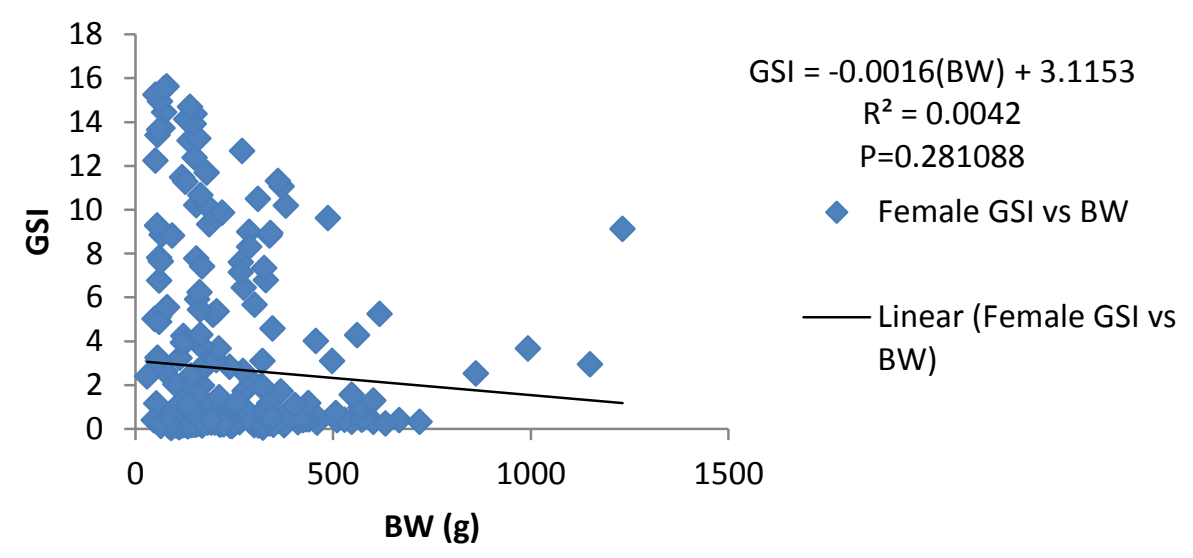

A)

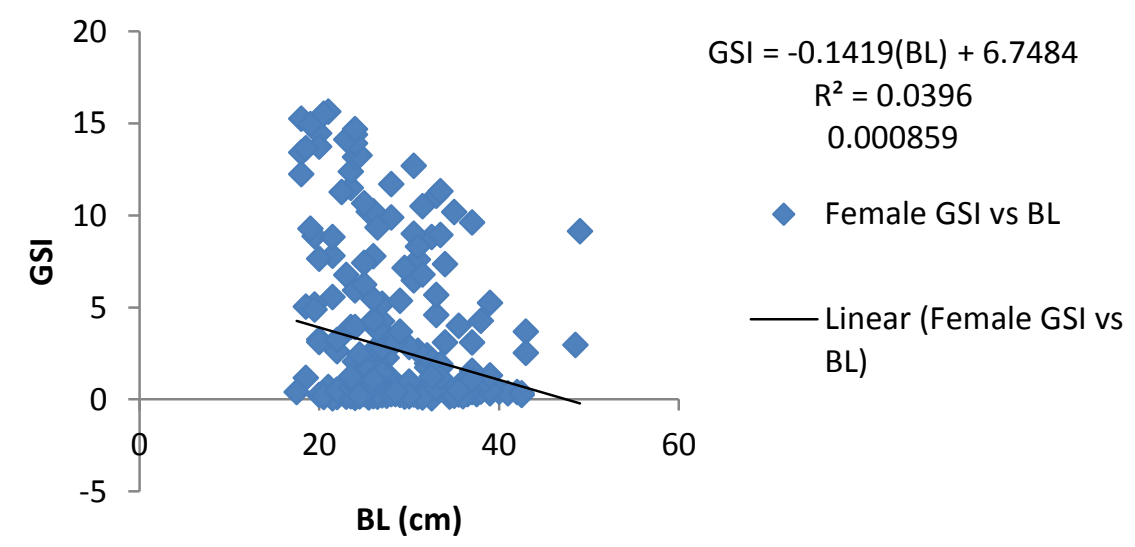

B)

Figure 6. GSI vs body weight and body length of the A. manilensis. (A) Female GSI vs body weight; (B) Female GSI vs body length 


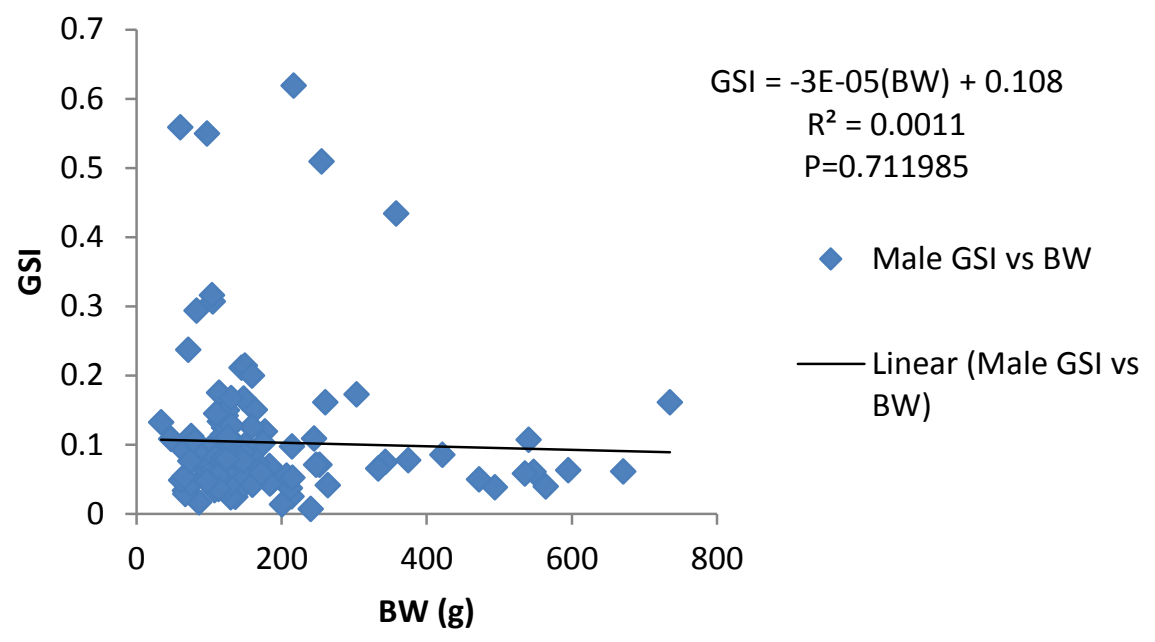

A)

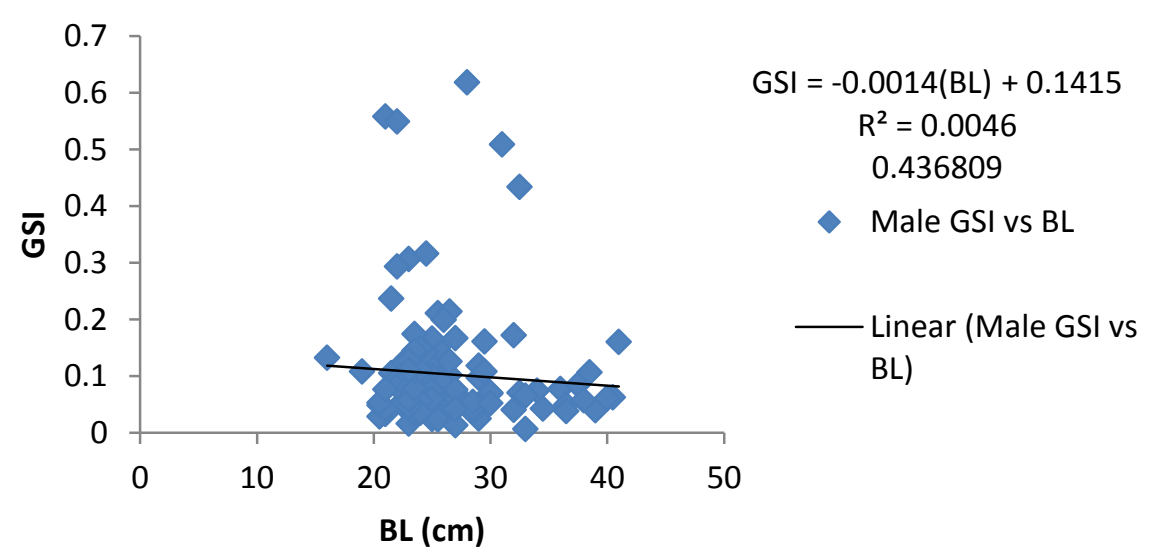

B)

Figure 7. GSI vs body weight and body length of the A. manilensis (A) Male GSI vs body weight (grams); b) Male GSI vs body legth length (centimeters)

Fecundity was correlated positively with both $\mathrm{BW},\left(\mathrm{r}^{2}=0.3708 ; \mathrm{P}=0.05\right)$ and $\mathrm{BL}\left(\mathrm{r}^{2}=0.3405\right.$; $\mathrm{P}=0.006$ ) at a high significance (Figure 8). Fecundity was also correlated positively with GW, $\left(\mathrm{r}^{2}=0.31096 ; \quad \mathrm{P}=0.0003\right)$ at a high significance (Figure 9).
The gonad weight was positively correlated with BW and BL for both sexes. The correlation was stronger for BW than for $\mathrm{BL}$, meaning that $\mathrm{BW}$ is a slightly better predictor of GW than BL (Figure 10). 


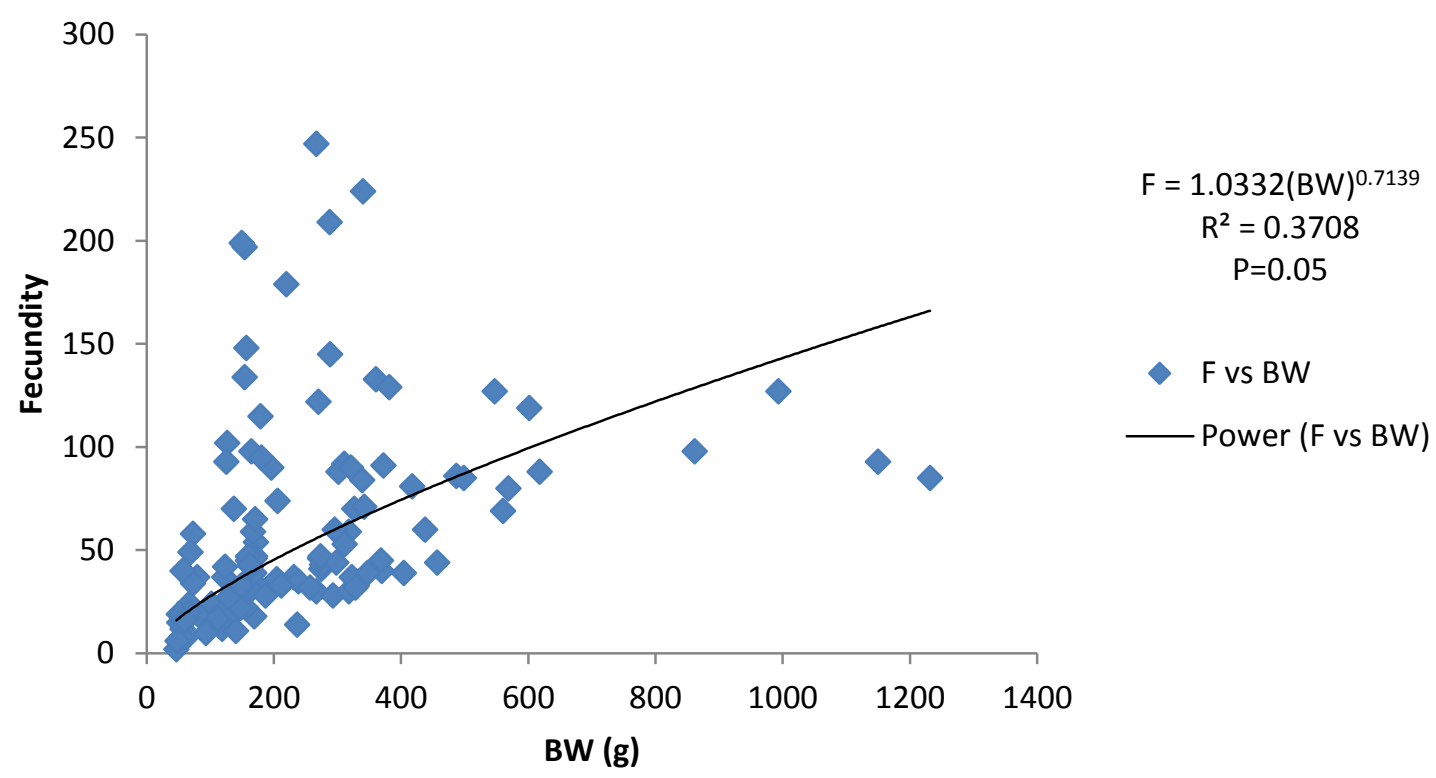

A)

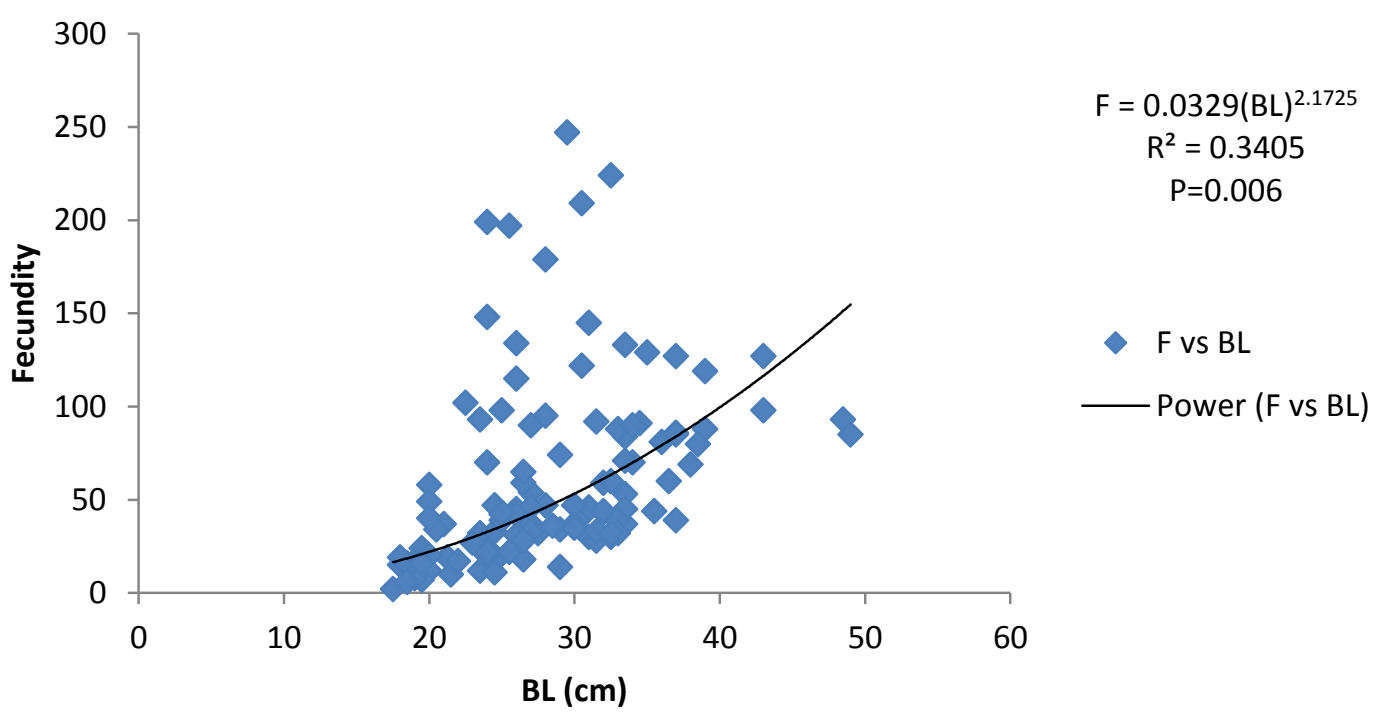

B)

Figure 8. Fecundity vs (A) BW (grams) and (B) BL (centimeters) 


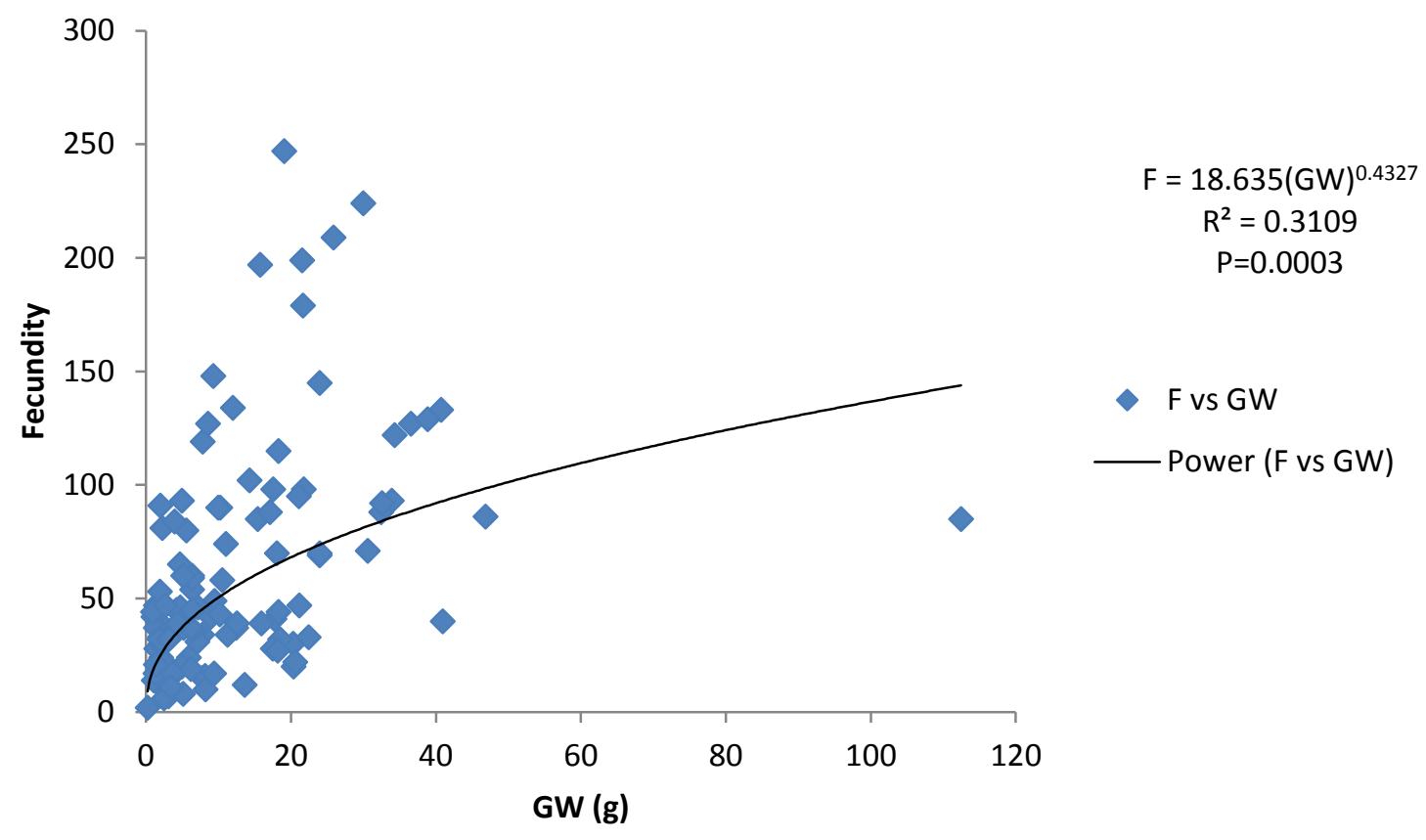

Figure 9. Correlation analysis of Fecundity vs Gonad weight (GW)

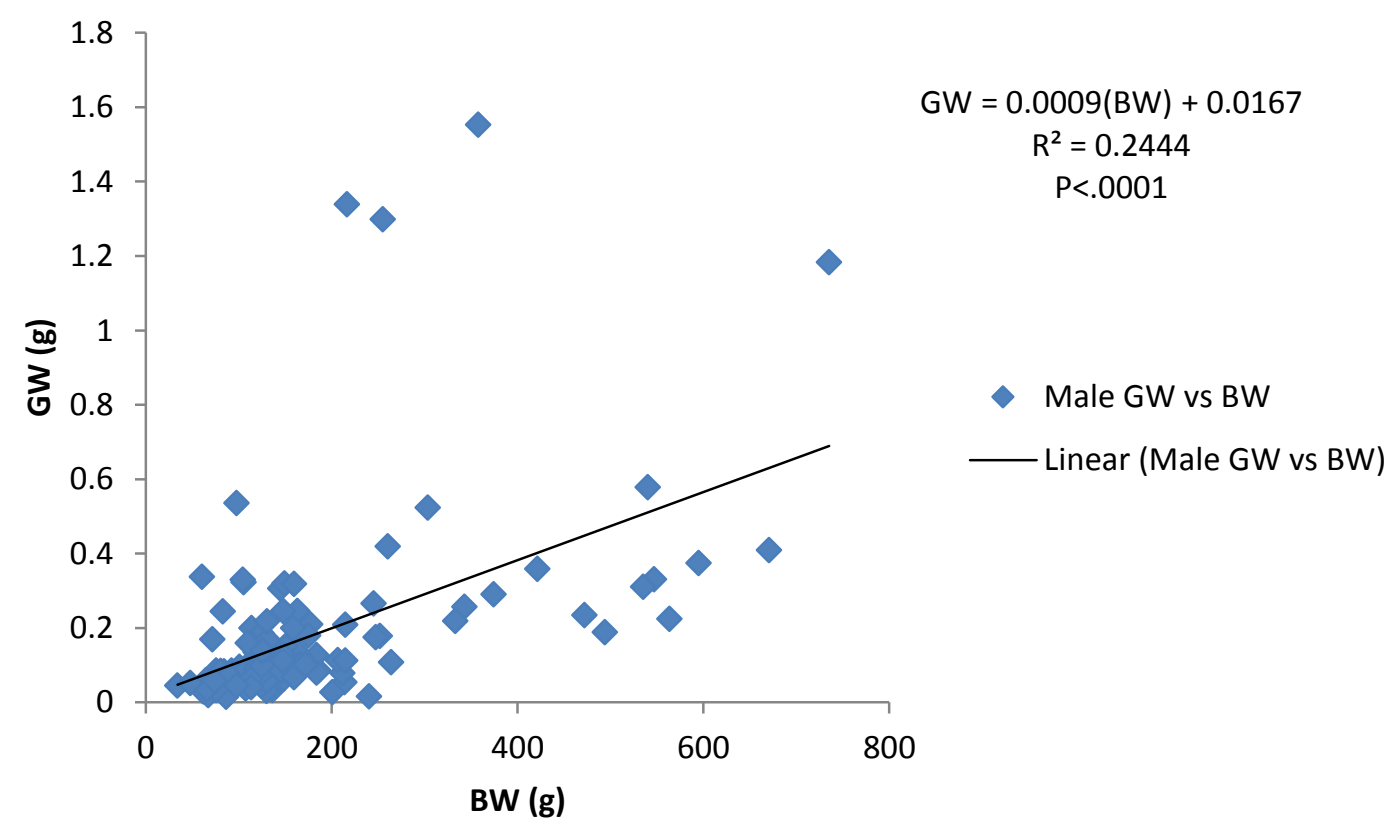

A) 


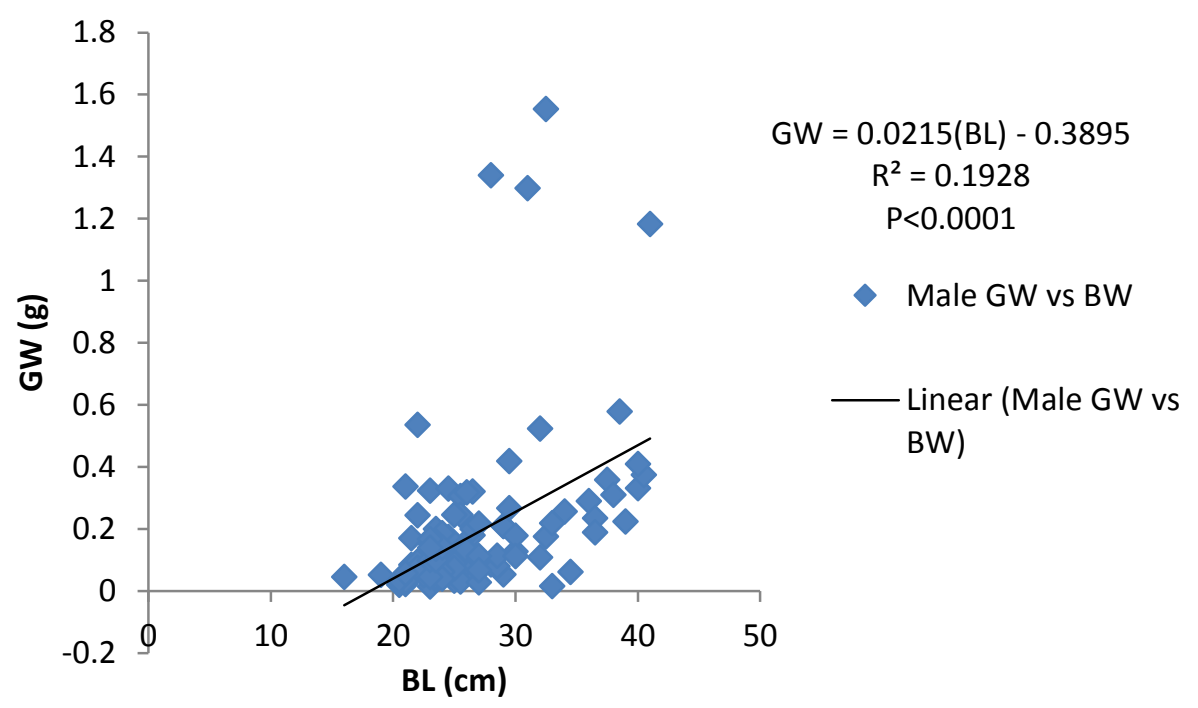

B)

Figure 10. Correlation analysis of Gonad weight vs (A) male BW (grams) and (B) male BL (centimeters) and (C) female BW (grams) and (D) female BL (centimeters)

\section{DISCUSSION}

A recent study on the reproductive biology of an estuarine catfish, Arius argyropleuron, in Malaysia, found that males outnumbered females over a 10-month sampling period (Mansor et al., 2012). Other studies by Rimmer and Merrick (1983) and Rimmer (1985) for A. graeffi in Australia and by Offem et al. (2008) for Chrysichthys nigrodigitatus, silver catfish, in Nigeria, also showed similar male over female population dominance. These catfish species are known as mouth-brooding fish, and this may account for the more numerous males compared to females (Mansor et al., 2012). Munoz et al. (2005) also found males numerically dominant for the marine Scorpaena notata.

This study found a different sex ratio of roughly 1 male: 2 females. This may reflect a different reproductive strategy for $A$. manillensis and possibly a faster growth rate for females relative to males. The observed sex ratio from the monthly population analysis may also have been affected by seclusion of the sexes during spawning, which can lead to different sex ratios (De Martini and Fountain, 1981; Alheit et al., 1984; Barbieri et al., 1992). The male "kanduli" incubates eggs in their mouths for a period of six to eight weeks and provide further care by sheltering them until they reach about 30 to $44 \mathrm{~mm}$ length (Rimmer and Merrick, 1983). During this time, they do not eat and lose weight tremendously (MendozaCarranza and Hernandez-Franyutti, 2005). Female A. manillensis might also be more competitive feeders than the males, which would be an advantage in securing sufficient nutrition for follicular development and spawning. The female numerical dominance over the male was at a maximum in the months of July to August and from November onwards to March. This may confirm the existence of a distribution pattern between males and females of A. manillensis 
in Laguna de Bay that is different from other catfish species.

In a study conducted on armored catfish (Liposarcus multiradiatus) in the Kaoping River of southern Taiwan, the sex ratio was female-biased (2.4:1) and this bias even increased during the reproductive season from March to September (Liang et al., 2005). This supports this study's findings and may indicate a similarity in reproductive biology between $A$. manillensis and $L$. multiradiatus. Females may also have a higher survival rate than males and males practicing parental care during the reproductive season have been proposed as a possible explanation (Mazzoni and Caramashi 1995). Roy and Hossain (2006) found highly significant male: female ratio of 1: 1.38 for Mystus cavasius (Hamilton) in Bengladesh. Pandey and Shukla (2013), in a review of fish reproductive strategies and behaviors, stated that marine male Arius and other catfishes have identical habits of carrying eggs in the mouth cavity until hatching. The male Brazilian catfish (Loricaria typus) protects and aerates the eggs in a lower labial pouch (Pandey and Shukla, 2013). Overall, this female dominance may be a rather unique reproductive strategy employed by $A$. manillensis in the muddy shallows of Laguna de Bay, where they are caught manually by fishermen. Male A. manillensis, may have evolved behavioural patterns that enable them to elude capture, as part of a survival mechanism to ensure the safety of the eggs they are brooding in their mouths.

The monthly mean GSI showing peaks in July to August and March and April indicate the projected two distinct spawning seasons of $A$. manilensis. This spawning pattern roughly parallels with the recorded peaks in fecundity which further validates the onset of spawning seasons during these months. Spawning appears to taper off during the colder months from September to February and the very dry months of May to June. Rimmer and Merrick (1983) observed that generally ariids have a single annual spawning corresponding to the beginning of the wet season in tropical species and spring in sub- tropical species. However, there is evidence of biannual spawning in $A$. caerulescens although fish may be observed in reproductive condition throughout the year (Rimmer and Merrick, 1983). For $A$. manilensis, it appears true that spawning corresponds to the beginning of the wet season in the Philippines (July). The second peak that occurs during the warm months of March to April could then be a distinct biannual spawning pattern of this ariid species in Laguna de Bay.

The cold months of September to February appears to favour a longer period of predicted breeding-to-maturation seasons than that of the warm months of May to June following the second peak of spawning season (March to April).

GSI correlations were unexpectedly almost zero for both BW and BL of male and female A. manillensis. This is in sharp contrast to many previous studies on GSI as a fish reproductive parameter. A very similar GSI versus standard body length was reported in the armored catfish $L$. multiradiatus, wherein GSI was observed to rise dramatically at $25 \mathrm{~cm}$ (Liang et al., 2005).

Based from the analysis of data where female GSI was clustered around 20-40 cm $\mathrm{BL}$, it appears that the possible onset of sexual maturity of female A. manillensis is around $20 \mathrm{~cm}$ in body length. A similar clustering of male GSI was also observed at 20 to $40 \mathrm{~cm}$ BL. This again suggests that sexual maturity in male A. manillensis 
occurs at around $20 \mathrm{~cm}$ in body length. Very little seasonal variation has been reported for the mature testes of ariids, being small and elongated for the most time (Lee, 1937; Tobor, 1969; Bishop et al., 1980. BW seems to be less reliable as an indicator of sexual maturity because GSI is quite evenly spread through a wide range of body weights. These findings support the possible follicular growth of the ovaries during the months prior to the spawning season of March to April.

This study found significant correlations between fecundity and body weight, body length and gonad weight. In the native European catfish, Silurus glanis L., 1758, fecundity correlated positively with total length, body weight and ovary weight (Alp et al., 2004). Fecundity was observed beginning at a body length of $20 \mathrm{~cm}$, while fecundity was predominant at a minimum of $200 \mathrm{~g}$ body weight. This supports the earlier proposed $20 \mathrm{~cm}$ sexual maturity marker in terms of body length and a possible $200 \mathrm{~g}$ body weight marker for sexual maturity of $A$. manillensis. Fecundity was also clustered around 10 to $20 \mathrm{~g}$ gonad weight.

Species, of GSI with BW, BL and GW. Similarly low correlations were recently reported for $A$. argyropleuron, specifically fecundity versus fork length $\left(r^{2}=0.2448\right)$ and fecundity versus body weight $\left(r^{2}=0.1529\right)$ (Mansor et al., 2012). For the small fish Punctius ticto which is indigenous in Bangladesh, body weight was more significantly correlated with total fecundity than total length, fork length, standard length, or ovary length (Hossain et al., 2012). However, fecundity did not show significant correlations with gonadosomatic index and other body parameters for Punctius ticto. In contrast, Bhatt et al. (1977) found that for four species of catfish, namely Mystus seenghala (Sykes), Mystus cavasius
(Ham), Wallagonia attu (Bloch) and Heteropneustes fossilis (Bloch), fecundity had a linear relationship with body weight and gonad weight, and, with the exception of $M$. seenghala, a parabolic relationship with length. Bhatt et al. (1977) concluded that a multiple regression analysis involving 2 variables correlated to fecundity gave the most accurate prediction of fecundity, namely body weight and length.

Three size classes of eggs are found in ariid ovaries, namely large yolky eggs, smaller yolky eggs and small hyaline eggs (1-2 cm) (Rimmer and Merrick, 1983). Mane (1929), Dmitrenko (1970) and Tasudevappa and James (1980) detailed diameters of oocyte classes of A. manillensis, $A$. thalassinus and A. dayii, and A. dussumieri, respectively. Rimmer and Merrick stated that fecundity measurements are small in comparison to other teleosts, and mature oocyte diameters can range from 9 to $25 \mathrm{~mm}$. The relationships between fecundity and body length, body weight and gonad weight have not been consistently reported (Pantulu, 1963; Tobor, 1969; Etchevers, 1978; Tasudevappa and James, 1980). The proportion of egg diameter classes showed a discernible cycle during the 12 months of monitoring. The smallest sized follicles peaked in August, dropped to a minimum in November, then peaked again in April. It was observed that the next larger class follicles increased as the smallest sized class decreased. The two largest class classes of follicles were maximum in September, November, February, June and July. These patterns loosely follow the proposed reproductive seasons of $A$. manilensis as it shows the wave pattern of follicular development that leads to spawning. In the related catfish species $A$. argyropleuron, egg diameter was classed into $3.88 \mathrm{~mm}, 7.20 \mathrm{~mm}$ and $11.19 \mathrm{~mm}$ groups for stage II gonads which were in final maturity, and $3.16 \mathrm{~mm}$ 
and $9.25 \mathrm{~mm}$ groups for stage III gonads which were ripe gonads (Mansor et al., 2012). The follicles in this study were not classified according to gonad stage, but similar class sizes were recorded. Ambily and Nandan (2017) observed that in $A$. subrostratus, the fecundity ranged from 11 to 34 eggs with an average of 22 eggs, supporting the observed low fecundity of catfish. They also reported that fecundity was linearly correlated with body length and weight, and also with gonad length and weight. Ariidae eggs are among the largest teleost eggs (Wallace and Selman, 1981). The distribution of eggs in terms of diameter reflects the 2 proposed spawning periods of A. manilensis, suggesting that this species is a multiple batch spawner.

In this study of A. manillensis, multiple correlation involving three variables, namely body weight, body length and gonad weight, can be used to predict fecundity. Gonad weight is not an option for use in the field, and therefore, body weight and length, taken together, are sufficient predictors of fecundity. The data observed in this study also supports the possibility that GSI is not a very precise indicator of reproductive potential in the Ariidae genera.

\section{CONCLUSION}

This study was able to establish the spawning seasons, fecundity and size at sexual maturity of this native ariid species of Laguna de Bay, Philippines. The two distinct spawning seasons were indicated by the peaks of GSI recorded in the months of March to April and July to August. These two distinct spawning seasons parallel those of the recorded peaks of fecundity. Fecundity was significantly correlated with body weight, body length and gonad weight. The size and weight of apparent sexual maturity or peak of reproductive capacity was about $20 \mathrm{~cm}$ and $200 \mathrm{~g}$, respectively. Harvesting of A. manillensis is therefore preferably done outside the peak months in order to maximize reproductive potential of this economically important species. Information presented in this study may aid in the development of regulations regarding the months for allowable fish catch to minimize possible depletion of population. Further, it specifies the best months to obtain fish samples for seeding into other inland waters in the Philippines.

Of further interest are studies on the sex hormone patterns in male and female fish at various stages of reproduction and sperm and oocyte analysis.

\section{DECLARATION OF CONFLICT OF INTEREST}

The authors declare no conflict of interest

\section{ACKNOWLEDGMENTS}

This research was funded by Project 19 F U 110 from the University Research Coordination Office, De La Salle University, Manila, Philippines.

\section{REFERENCES}

Alheit J., Alarcon V., and Macewicz B.J. (1984). Spawning frequency and sex ratio in the Peruvian anchovy, Engraulis ringens. Calif. Coop. Fish Invest. Rep. 25: 43-52.

Ambily, V. and Nandan S.V. (2017). Studies on some aspects of reproductive biology of Shovelnose catfish, Arius subrostratus (Valenciennes, 1840) 
from Cochin estuary, India. Int. J. Fisheries and Aquatic Studies. 5(5): 165-171.

Alp A., Kara C., and Buyukcapar H.M. (2004). Reproductive biology in a native European catfish, Silurus glanis L., 1758, population in Menzelet Reservoir. Turk J. Vet. Anim. Sci. 28: 613-622.

Barbieri L., Dos Santos R., and Andreata J. (1992). Reproductive biology of the marine catfish, Genidens genidens, in the Jacarepagua Lagoon system, Rio de Janeiro, Brazil. Environ. Biol. Fishes. 35: 23-35.

Bhatt V.S., Dalal S.G., and Abidi S.A.H. (1977). Fecundity of the freshwater catfishes Mystus seenghala (Sykes), Mystus Cavasius (Ham), Wallagonia Attu (Bloch) and Heteropneustes fossilis (Bloch) from the plains of northern India. Hydrobiol. 54: 219224.

Bishop K.A., Allen S.A., Pollard D.A., and Cook M.G. (1980). Ecological studies on the fishes of the Alligator Rivers Region - autecological studies. Report for the Office of the Supervising Scientist of the Alligator Rivers Region, Sydney (Unpublished).

De Graaf, G. (1994). The artificial reproduction and pond rearing of the Africancatifish Clarias gariepinus.http://www.fao.org/tempr ef/FI/CDrom/aquaculture/a0845t/vol ume1/docrep/field/003/ac578e/AC57 8E00.htm (accessed May 8, 2019).
De Martini E., and Fountain R. (1981). Ovarian cycling frequency and batch fecundity in the queenfish, Seriphus politus: attributes representative of serial spawning fishes. Fish.Bull., 79: 547-560.

Dmitrenko, EM. 1970. Reproduction of the sea catfish (Arius thalassinus Ruppel) in the Arabian Sea. J. Ichthyol. 10: 634-641.

FAO. 1972. Report to the Government of the Philippines on fish culture development in Laguna de Bay. Based on the work of Yoel Prugunin. FAO/TA Fish Culturist.Rep. FAO/UNDP (TA), (3062): 35p.

Etchevers, SL. 1978. Contribution to the biology of the sea catfish, Arius spixii (Agassiz) (Pisces - Ariidae), south of Margarita Island, Venezuela. Bull. Mar. Sci., 28: 381-385.

Fishbase.org.Arius manillensis Valenciennes, 1840. http://www.fishbase.org/country/Cou ntrySpeciesSummary.php?c code $=608 \& i d=27634$.

(accessed February 11, 2014).

Gupta S. and Banerjee S. (2013). Studies on some aspects of the reproductive biology of Amblypharyngodon mola. Intl Res J of Biol Sci 2: 69-77.

Hossain M.Y., Rahman M.M., and AbdallahE.M. (2012). Relationships between body size, weight, condition and fecundity of the threatened fish Puntius ticto (Hamilton, 1822) in the Ganges River, northwestern Bangladesh. Sains Malaysiana. 41: 803-814. 
Lee G. (1937). Oral gestation in the marine catfish Galeichthys felis. Copeia. 37(1): 49-56.

Liang S-H., Wu H-P., and Shieh B-S. (2005). Size structure, reproductive phenology, and sex ratio of an exotic armored catfish (Liposarcus multiradiatus) in the Kaoping River of southern Taiwan. Zool Studies 44: 252-259.

Mane A.M. (1929). Preliminary study of the life history and habits of kanduli (Arius sp.) in Laguna de Bay. Philippines Agri. 18: 1-117.

Mansor M.I., Nurul S.M.N., Khairun Y., and Siti A.M.N. (2012). Reproductive biology of estuarine catfish, Arius argyropleuron (Siluriformes: Ariidae) in the northern part of Peninsular Malaysia. J of Biol, Agric and Healthcare. 2: 14-28.

Marcano D., Cardillo E., Rodriguez C., Poleo G., Gago N., Guerrero H. (2007). Seasonal reproductive biology of two species of freshwater catfish from the Venezuelan floodplains. Gen and Comp Endoc 153: 371-377.

Mazlan, A. G and Abdullah, S and Shariman, M. G and Arshad, Aziz (2008). On the biology and bioacoustic characteristic of spotted catfish Arius maculatus (Thunberg 1792) from the Malaysian Estuary. Research Journal of Fisheries and Hydrobiology. 3(2): 63-70.

Mazzoni R., and Caramaschi E.P. (1995). Size, structure, sex ratio and onset of sexual maturity of two species of Hypostomus. J of Fish Biol 47: 841849.
Mendoza-Carranza M., and HernándezFranyutti A. (2005). Annual reproductive cycle of gafftopsail catfish, Bagre marinus (Ariidae) in a tropical coastal environment in the Gulf of Mexico. Hidrobiol. 15:275-282.

Mercene E.C. (1978). Kanduli (Arius spp.) population of Laguna de Bay, Philippines. Phil. J. Fish. 16: 1-24.

Munoz M., Sabat M., Vila S., and Casadevall M. (2005). Annual reproductive cycle and fecundity of Scorpaena notata (Teleostei: Scorpaenidae). Scient Mar 69: 555-562.

Offem B.O., Akegbejo-Samsons Y., and Omoniyi I.T. (2008). Diet, size and reproductive biology of the silver catfish, Chrysichthys nigrodigitatus (Siluformes: Bagridae) in the Cross River, Nigeria. International Journal of Tropical Biology. 56: 1785-1799.

Pandey, K., and Shukla J.P. (2013). Fish and Fisheries. $3^{\text {rd }}$ ed., pp. 588, Rastogi Publications: New Delhi, India.

Pantulu, VR. 1963. Studies on the age and growth, fecundity and spawning oi Osteogeneiosus militaris (Linn.). Cons. perm. int. Explor. Mer. 28: 295-315.

Rimmer M.A. (1985). Reproductive cycle of the fork-tailed catfish Arius graeffei Kner \& Steindachner (Pisces: Ariidae) from the Clarence river, New South Wales. Australian J of Mar and Freshwat Res. 36: 23-32.

Rimmer M.A., \& Merrick J.R. (1983). A review of reproduction and development in the fork-tailed 
catfishes (Ariidae). Proc. Linn. Soc. N.S.W. 107: 41- 50.

Roy P.K., and Hossain M.A. (2006). The fecundity and sex- ratio of Mystus cavasius (Hamilton) (Cypriniformes: Bagidrae). J. Life Earth Sci.1: 65-66.

Santos B.S. and Quilang J.P. (2012). Geometric morphometric analysis of Arius manillensis and Arius dispar (Siluriformes: Ariidae) populations in Laguna de Bay, Philippines. Phil. J. Sci. 141 (1): 1-11

Sarkar U., Kumar R., Dubey V., Pandey A., \& Lakra W. (2012). Population structure and reproductive biology of a Freshwater Fish, Labeoboggut (Sykes, 1839) from two perennial rivers of Yamuna Basin. J. Applied Ichthyol [0175-8659]; 28: 107-115.

Tasudevappa, C. and James P.S.B.R. (1980). Maturity and spawning of the marine catfish, Tachysurus dussumieri (Valenciennes) along the South
Kanara coast. Proc. Indian Natl. Sci. Acad. Part B Biol. Sci. 46: 90-95.

Tobor J.G. (1969). Species of the Nigerian ariid catfishes, their taxonomy, distribution and preliminary observations on the biology of one of them. Inst. Jr. Afr. noire Ser. A. Sci. Nat., 31: 643-658.

Vallejo J. (1985). Fisheries of Laguna de Bay. Nat. Appld. Bull. 37: 298-299.

Wallace R.A. and Selman K. (1981). Cellular and dynamic aspects of oocyte growth in teleosts. American Zoologist. 21(2): 325-343.

$\mathrm{Yu}$ S.S. and Quilang J. (2015). Morphological and molecular analysis of the sea catfishes Arius manillensis and Arius dispar (Siluriformes: Ariidae). Phil. Agric. Scientist 98(1):32-46. 